\title{
The Representation Of Nobita Weakness In Doraemon Stand By Me Film
}

\author{
Rima Novia Ulfa ${ }^{1}$, Rr.Astri Indriana Octavita ${ }^{2}$, Sugianti Somba $^{3}$ \\ 1,2,3 Universitas Indraprasta PGRI \\ ${ }^{1}$ rymanovia@gmail.com, ${ }^{2}$ mrs.astriindriana@gmail.com, ${ }^{3}$ sombacute08@gmail.com

\begin{tabular}{ccc}
\hline Diterima & Direvisi & Disetujui \\
$22-01-2020$ & $13-03-2020$ & $16-03-2020$ \\
\hline
\end{tabular}

\begin{abstract}
The development of animated films in the world has created various animated characteristics of the results that have been made. The results that have been made are from several animated film studios, namely, animated films from America, Europe to Asia, especially Japanese animated film Based on that, the researcher intends to examine the representations of Nobita, Doraemon's best friend. Literature intended for children is a literary work that contains the world of children, which is much related to the system of language and signs, which are used in accordance with the level of intellectual and emotional development of children. Anime 2112 Nen Doraemon Stand by Me is the work of director Yonetani Yoshimoto with duration of about 1.5 hours. Doraemon is a cat robot that was mass produced by a factory in 2112. This research aims to obtain information about: portrayal of manga characters Doraemon's special story, namely Doraemon Stand by Me. The story in this anime is interesting to the writer because the author found a sign in the form of a marker (signifier) from the figure of Nobita. Nobita which shows the existence of several signs that refers to his representation. By using qualitative methods and accompanied by semiotic theory and representation of Barthes, as a research scalpel. The limitation of the problem in this study focused on the sign of Nobita's figure by analyzing the building elements, namely the element of narrative. In this research, researchers used the theory of semiotics, to interpret hidden meaning in the film Doraemon. The method used in this research is qualitative method. As for the desired results, researchers can show a representation of Nobita in the Doraemon film.
\end{abstract}

Keywords: representation, semiotic, sign, film, doraemon

\begin{abstract}
Abstrak- Perkembangan film animasi di dunia telah menciptakan beragam karakteristik animasi dari hasil yang sudah ada sebelumnya. Hasil yang sudah ada dibuat dari beberapa studio film animasi, yaitu, film animasi dari Amerika, Eropa ke Asia, terutama film animasi Jepang. Berdasarkan hal tersebut, peneliti bermaksud untuk meneliti representasi Nobita, sahabat Doraemon. Literatur yang ditujukan untuk anak-anak adalah sebuah karya sastra yang berisi tentang dunia anak-anak, yang banyak terkait dengan sistem bahasa dan tanda-tanda, yang digunakan sesuai dengan tingkat perkembangan intelektual dan emosional anak-anak. Anime 2112 Nen Doraemon Stand By Me adalah karya sutradara Yonetani Yoshimoto dengan durasi sekitar 1,5 jam. Doraemon adalah robot kucing yang diproduksi massal oleh sebuah pabrik pada tahun 2112. Penelitian ini bertujuan untuk memperoleh informasi tentang: penggambaran karakter manga pada kisah Doraemon, dalam fim Doraemon Stand By Me. Kisah dalam anime ini menarik bagi penulis karena penulis menemukan tanda berupa penanda (penanda) dari sosok Nobita. Metode yang digunakan adalah metode kualitatif dan disertai dengan teori semiotik dan representasi Barthes. Keterbatasan masalah dalam penelitian ini difokuskan pada tanda sosok Nobita dengan menganalisis unsur yang dibangun, yaitu unsur narasi. Dalam penelitian ini, peneliti menggunakan teori semiotika, untuk menafsirkan makna tersembunyi dalam film Doraemon. Metode yang digunakan dalam penelitian ini adalah metode kualitatif. Adapun hasil yang diinginkan, peneliti dapat menunjukkan representasi Nobita dalam film Doraemon.
\end{abstract}

Kata Kunci:: represntasi, semiotik, tanda, film, doraemon

\section{INTRODUCTION}

Mass media is a part of communication, Mass media in terms; it is the understanding of mass communication is radio, newspapers, magazines, television and films. Without emotion, mass media will also be very boring. Emotion is one important aspect of life. Related to the problem 
above, Sobur (2009: 14) explained that: "Film has the ability to play space and time and develop and shorten freely within the boundaries of a fairly spacious area".

The mass media is actually in the middle of social reality which is loaded with various kinds of interests, conflicts, and complex and diverse facts. The mass media is called as one of the foundations in social, economic and political life. As a tool to convey news, assessments, or a general picture of many things, the mass media has the ability to act as an institution that can develop into a pressure group on an idea or an idea, and even an interest or representation, which is represented to be placed in the context of life that is more empirical. Despite the many negative effects produced by mass media products. But the mass media has played an important role in providing information knowledge to entertainment for a wide audience. Besides the mass media also open up jobs for many people. Through organizations engaged in the business of the media industry.

The development of animated films in the world has created a various animated characteristics of the results that have been made. The results that have been made are from several animated film studios, namely, animated films from America, Europe to Asia, especially Japanese animated films, which have their own characteristics. These characteristics become a differentiator between Japanese animated films, American and European animated films. According to Donald Richie (1961: 1) in his book Japanese Cinema is: "If the American film is strongest in action, and if the European is strongest in character, then the Japanese film is richest in mood or atmosphere, in presenting characters in their own surroundings".

Film studies can be said to be a relatively new field of study and not comparable to the process of technological evolution. The exploitation of film studies, which occurred in the 60-70s in Europe and America, did not bring much change. Desire to produce a holistic approach in multidisciplinary and interdisciplinary film studies, which still seems to be wishful thinking. Film is seen in the context of Communication Science. Although film is an integral part in the field of Language and Communication, however, over time, the animation film industry helped expand the space for animation films both in terms of storytelling, images (visuals), and themes so that the audience segment expanded which was not only for children who were the main goal. (Biagi, 2010: 169) "The nature of imaginative and creative films can make the film industry as" Industry, which is built from dreams. "High imagination is needed for directors in filmmaking to serve as a form of communication in delivering messages to interpret signs.

Film, including animation film has its own artistic value, because the film is created as a work of creative personnel who are professionals in their fields. Film as an art object should be judged artistically not rationally. Film is not new to society anymore. Common reasons, film means a part of modern life and is available in various forms, such as in cinemas, television shows, in video tapes, and laser discs. Film not only provides an exciting experience, but also everyday life experiences that are attractively packaged

Children's literary works usually contain educational themes, the plot is straight and not complicated, using settings that are around or in the world of children, characters and characterizations using good examples, language styles are easy to understand, able to develop children's language, and imagination is still within the reach of children. With the media of children's literature, in addition to imitating good deeds, children become more advanced in their imagination. One medium of children's literature is anime. Anime is a term used to refer to Japanese animated films, like doraemon. The word anime is an absorption language from English "animation" and is pronounced as "animeshon". According to Hernadi, (2013:1) "Anime memiliki berbagai macam genre sesuai jenis penontonnya, mulai dari kodomo yang ditujukan untuk anak-anak, shoujo untuk anak perempuan, shounen untuk anak laki-laki, mecha untuk penggemar robot, dan seinen untuk penonton dewasa".

An animated or anime film is generally built with signs. These signs include various sign systems that work well together to achieve the expected effect by using iconic signs, namely signs that describe something (Zoest in Sobur, 2009: 128). In an anime usually have signs that have an implicit meaning. The meaning contained in the anime is related to the relationship between characters and relationships between events that are built in the anime. This meaning can be seen from the use of signs studied in semiotics.

Japan is one country that has developments in the world of film, especially developments in Japanese animated films. Japanese animation films are very famous in Indonesia. Japanese animated films, which are very well known in Indonesia and are still remembered today, namely, Naruto, Shin Chan, Conan, Doraemon and 
many more. This film is a legendary Japanese animated film that is very famous in Indonesia. A culture is a benchmark for the level of progress of a nation. In this case, Japan is one of the many nations that have a high level of culture, where they created the most spectacular and longest-lived manga figure in history, namely Doraemon. Fictional story, which is set up in Japanese culture neatly and carefully by its author, Fujiko F. Fujio and able to compete with the world-famous cartoon films industry such as Mikey Mouse, Donald Duck from America and others. The appearance of Doraemon with his magic bag is able to provide different touches in this film, where Doraemon is told is not a robot or a super hero who is completely perfect, and so is his friend, Nobita

The legendary Japanese animated film that is very popular today is the Doraemon Serial film. The characteristics of Japanese animation have many good sides, because it only contains one idea. Characteristics of cartoons using caricature, exaggerated satire, symbolism and choice of humor. Humor often and often makes people laugh, especially in animated films, which contain political opposition to newspaper readers. The power of film animation to influence public opinion lies in its cohesiveness, simplification of issues, and attention, which can really be raised sharply through humorous images. Cartoons are a source of information that is digested through strong visual impact.

Doraemon's film series as Indonesia's legendary animated film has created a good appreciation for Indonesian children. Doraemon's film series is one of the concrete proofs of the development of Japanese animated films. Japanese people recognize the term Japanese animation as an anime. Anime is a term used to refer to animated films. The word comes from the word animation, which in Japanese pronunciation becomes an animeshon. The word was later shortened to anime. Although basically anime is not intended specifically for Japanese comics, most people use the word to distinguish between Japanese and nonJapanese animated films.

In middle of 2014 , the latest was released from the Doraemon film series, which showed the development of characters from the Doraemon movie series itself to its 3-dimensional version. Right on August 8, 2014 the 3-dimensional version of Doraemon film was released by Trick Block Co Animation Studio entitled Doraemon Stand by Me. This Doraemon Stand By Me film made the audience amazed by the animation that was made, because the characteristics of the Doraemon film series itself were increasingly emphasized. This Doraemon Stand By Me film looks really real, so the core of the film can be conveyed well to the audience. The movie Doraemon Stand by Me, has a very visible character, one of them is Nobita. In this film, Nobita that we know from Doraemon comics or movie series, has very standard display characteristics, now in the Doraemon Stand by Me movie the display characteristics can look really real with their representation

In acting, although the actor is cartoons, language is indeed the main element. In Language Science stated that the communication process in primary is the process of conveying one's thoughts or feelings to others by using symbols (symbols) as media. Symbols as primary media, in the process of communication are language, cues, images, etc., which are directly capable of translating the communicator's thoughts and feelings to communication. That the most widely used language in communication is clear because it is only capable language translate someone's thoughts to others, whether is in the form of ideas, information or opinions, both concerning things that are concrete and abstract.

The presence of imaging elements of a character is presented at the film made a visual sign on Nobita's character. Danesi, (2011: 75) was told, "Visual sign can be defined simply as a sign constructed with a visual marker, which means with a marker, which can be seen (not heard, touched, tasted, or kissed)." Visual sign of Nobita's character in the film Doraemon Stand by Me is the beginning of the form of identity transformation that was presented. In the process of forming a text, meaning is not only imposed on external objects. Interpretation activity is also a process of selfdiscovery and the understanding of each interpretation of a symbol is an interpretation and self-transformation that is imagined. The meaning never just happens, because making meaning is an activity that takes time. Thus the formation of meaning is something that is creative, widespread, and very subjective. So the meaning is diverse and varied

From the discussion above, the theory is obtained for the assessment process. Then an assessment was made that the visual transformation of Nobita's characters included form, costume, and personality. The visual transformation of characters referred to here is by the division of visual elements of characters using the Manga Matrix method. In the distribution of visual elements, it was identified that, given the change in the character of Nobita's children, Nobita became an adult in the content of 
the story. This is what makes Nobita experience a transformation of visual identity. Then in the study of the visual identity of Nobita characters, researchers used Pierce's semiotics to obtain the visual identity of Nobita's character, which was read through the study of representamen, object and interpretants in the film Doraemon Stand by Me

From the discussion above, a theory is obtained for the assessment process. Then a study is carried out, character transformation Nobita includes form, costume, and personality. For this reason, the researcher intends to use Semiotics as a tool to dissect meaning and identity. The reason the author chose visual characters from Nobita because of the visual character itself there is a development of identity in inside, then departing from the above problems raises questions as a statement of problem. The first problem would be How Nobita's character is a very influential figure in the film Doraemon Stand by Me. The second question would be: What is the visual identity of Nobita's character in the Doraemon film Stand by Me? The purpose of this research is to understand the visual image of Nobita's character in the movie Doraemon Stand by Me. In addition, to understand the visual identity of Nobita's character in the movie Doraemon Stand By Me.

Words or languages, in linguistic vehicles, are given a meaning as a system of sound symbols meaningful and actualizing, which is arbiter or changeable and conventional, which is used as a communication tool by a group of humans to give birth to feelings and thoughts. Language is a combination of words arranged systematically, so that they can be used as communication tools. The word itself is an integral part of the symbol, which is used by community groups. First of all it will be difficult to imagine something that is not open to various interpretations and uses; it will be very difficult to find the intended meaning. Symbols can give other meanings to other people too, and can even mean different things to the same person. At different times or different circumstances a text can be interpreted by the same person differently.

By using Roland Barthes's semiotic analysis that focuses on the sign, the researcher tries to analyze and answer the question of how the child's identity is represented in the animation Doraemon Stand by Me. In the theory of semiotics, the process of interpreting ideas, knowledge, or messages physically is called representation. Representation means using language to express something meaningfully, or to present it to others. Representations can be in the form of words, images, sequences, stories, etc. that represent ide ideas, emotions, facts, and so on. Representations depend on existing signs and images. By using cultural semiotic analysis and being restricted to the area of non-verbal communication studies, researchers tried to interpret what the author wanted to convey through this cartoon media.

The scope of this aim is that the research that the author does can focus on a problem. This research is a library research, because the material studied is library material in the form of serial films, various journals, articles and also books that support this research. The scope of this research is about studying Nobita's character as the main character in the Doraemon comics by using a semiotic approach, which discusses the sign elements in the animated film Doraemon the series, by Fujiko F. Fujio.

Interpreting signs is the main goal of semiotics, however although semiotics observes that something can be used to symbolize anything else, Roland Barthes sees signs as a means of communication of an ideology, has connotation meaning to reinforce the dominant value in society. Barthes means that the connotation is a label containing a sign device that is always carried at any time. In the process of sign meaning, Barthes saw that there must be signifier, and signified who work together to combine signs. Signifier is mind while signified are hidden thoughts because when the process of meaning is carried out, individuals already have a variety of backgrounds and experiences that indirectly, will be the basis for interpreting something. As illustrated by Saussure, who said that, the sign is like a paper that is significant on one side while the other side is signified. If it is cut in the middle, it will get both of them.

This problem is in lined with what Kurniawan said, 200 1: 50), which says "Narratives need special attention because according to Aristotle, narratives are speech words that are signs of affection of the soul, and written words are signs from utterances, just as all humans do not have the same writing, so all humans do not have the same voice of speech, but affections if those marked by speech are the same for everything, as well as things from experience -our experience is images According to Barthes in Lyons, Pateda, (2001: 98). "Denotation is the relationship used in the first level to a word that freely plays an important role in speech. (The denotation meaning is direct, that is, the special meaning contained in a sign, and can basically be called as an illustration of a sign So, it can be said that denotation as the meaning of a word or group of words is based on the 
appointment, which is straightforward on something outside the language or which is based on certain conventions that are objective.

Examining the meaning of representation, Chris Barker "mentions that representation is the main study in cultural studies." Representation itself is defined as how the world is constructed socially and presented to us and by us in certain meanings. Cultural Studies focuses on how the process of meaning representation itself .Representation means using language to express something meaningfully, or to present it to others. Representations can be in the form of words, images, sequences, stories, etc. that represent ideas, emotions, facts, and so on. According to Hartley, (2010: 265), Tang said that "Representation depends on signs and images that already exist and are understood culturally, in language learning and various markings or textual systems reciprocally. This is through a sign function ' representing who we know and study about reality" Relating to Nabota's representation, the researcher would like to investigate, if Nobita might not do anything, without Doraemon.

\section{RESEACRH METHODOLOGY}

To support this research, the authors use qualitative research methods. According to Yusuf (2014: 328) "Qualitative research seeks meaning, understanding, and verstehen about a phenomenon, event, or human life by being directly and / or indirectly involved in the researched, contextual and comprehensive settings". In this study, researchers finally used qualitative research methods to explain, step by step and meaning, which was concluded during the research process, starting from the beginning to the end, which is narrative. Then the researcher uses a cultural studies approach, which focuses on an identity. The researcher tried to understand the meaning of an event or event brought by Nobita's character in the movie Doraemon Stand by Me from mise-en-scene in order to get a visual identity that the researcher wanted to look for.

While the connotation meaning is interpreted as an aspect of a meaning or group of words based on feelings or thoughts that arise or are generated on the speaker or writer and listener or reader. This is reinforced by Barthes in Mulyana, (1997: 125) "If the denotation of a word is the objective definition of the word, then the connotation of a word is its subjective or emotional meaning". This is in line with the opinion of Arthur
Asa Berger (2000: 15). Which states that "connotation words involve symbols, history, and things related to emotional"

\section{FINDING AND RESULT}

Doraemon can be categorized as children's literature. Kurniawan, (2000, 22) argues: "Children's literature is a literary work that contains about the world of children and language, which is used in accordance with the level of intellectual and emotional development of children". Children's literary works usually contain themes that educate, the path is straight and not convoluted, using existing settings around or in the world of children, characters and characterizations use good examples, the language style is easy to understand, able to develop children's language, and imagination is still within the reach of children

Based on all the above explanations, the author became interested in making Nobita's character as the object of research. The purpose of this study, to find out the figure of Nobita in depth, in the sense that there will be a study focusing on the visual of Nobita's character, where the visual character brings a development of identity and meaning, found in the character Nobita in Doraemon: Stand By Me. Animation is a collection of images that are processed in such a way as to produce movement. "Multimedia animation is the process of forming motion from various media or objects that are varied with effects - effects and filters, transition movements, sounds - sounds that are in harmony with the animation movement. Because this type of show is very popular in their environment, not even a few adults like this animated show.

Doraemon is the title of a popular comic or manga written by Fujiko. Fujio since 1969 and tells about the life of a lazy fifth grade elementary school child, named Nobita who was visited by a cat robot named Doraemon who came from the 22nd century. Doraemon was sent to help Nobita so that Nobita's descendants could enjoy his success. 
Table 1. Sign

\begin{tabular}{|l|l|l|}
\hline & \multicolumn{1}{|c|}{ Framer } & Form \\
\hline $\begin{array}{l}\text { Sign: } \\
\text { expression } \\
\text { field }\end{array}$ & \multicolumn{1}{|c|}{$\begin{array}{l}\text { Expression: } \\
\text { Nobita as a } \\
\text { child who } \\
\text { is weak and } \\
\text { stupid }\end{array}$} \\
\hline Sign: & $\begin{array}{l}\text { Sad } \\
\text { Doraemon lives him } \\
\text { alone }\end{array}$ & $\begin{array}{l}\text { Form: } \\
\text { Doraemon } \\
\text { as the Myth } \\
\text { of a helper } \\
\text { god }\end{array}$ \\
\hline
\end{tabular}

Rather than having to suffer from debt financial situation that will occur in the future caused by Nobita's stupidity. Therefore Nobita is the main character in the Doraemon animated film.

Doraemon. The magic cat robot that is told, he was 'born in 2112, with having round shape from head to toe is very popular with various groups, children, teenagers or parents. His expertise in removing sophisticated objects of future creation is useful to help Nobita Nobi, a lazy man, careless and likes to take a nap, when in trouble (which Nobita usually brings his own problems). Doraemon was created by Fujiko. F. Fujio, as a good-minded robot, a loyal friend of man, Nobita, Dorayaki lovers and likes to help anyone who needs it. Doraemon's daily comics bring his readers to joy because the substance of the story is full of imaginations and imaginations about the sophisticated gadgets, friendship \& delinquency Nobita and his friends, humorous while introducing the distinctive style of Japanese culture.

Doraemon animation can survive in Indonesia because of the number of enthusiasts from this show. Starts from children to adults. This is because the animated shows Doraemon and Nobita contain many positive values for children, such as values of honesty, the value of character education, and others. Looking at the current phenomenon, what has happened in Indonesia is that there is very little quality spectacle for children. Many theories have emerged about the origin and end of this series of stories. One of them emerged from the theory of fans as outlined in the manga work resembling the work of Fujiko F, Fujio. It's so cool, the picture is very similar. In fact, many people think that the manga is the final story of Nobita's official life.

In the film Doaemon, since the initial episode, Nobita is always portrayed as a weak anal figure. In 'Stand by me', we will look back at the amazing, legendary items that Doraemon has in his magical pockets such as "the door to anywhere" and "behind the bamboo". Takashi Yamazaki who also wrote the screenplay also gave us a familiar picture of the pathetic nature of Nobita who always depends on Doraemon, her obsession with Shizuka and how patiently Doraemon always helped Nobita.Things that we have never seen before in 'Stand By Me' are the motivation for Doraemon's presence in Nobita's life. We are told that the beginning of Doraemon came to Nobita's life, how Doraemon felt before knowing Nobita and how he felt after getting to know the boy. Also interesting in 'Stand by Me' is a deadline about how long Doraemon will stay and be a helper for Nobita at any time. Things we never knew before in the animated series. In this table, we would see how Nobita might show:

From table, we would see that things that we have never seen before in 'Stand by Me' are the motivation for Doraemon's presence in Nobita's life as the representation. We are told that the beginning of Doraemon came to Nobita's life, how Doraemon felt before knowing Nobita and how he felt after getting to know the boy. Also interesting in 'Stand by $\mathrm{Me}^{\prime}$ is a deadline about how long Doraemon will stay and be a helper for Nobita at any time. Things we never knew before in the animated series. The weakness of Nobita is also shown in the picture below:

\section{Picture 1. Expression}

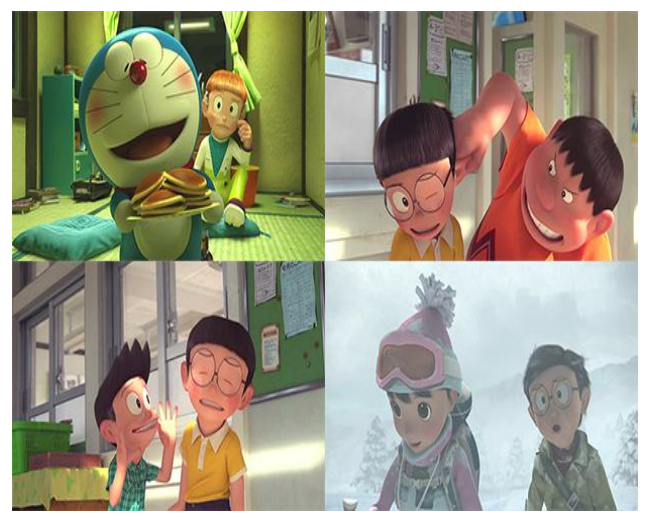

Based on the perspective expressed by Barthes, Giant and Suneo are part of the sign of Nobita's weakness, in the signification system. 
Giant in the film represents humans, who are arrogant and who assume, that he is the one who holds control over what is in nature, the environment, and its surroundings. In the picture, Nobita surrenders to the force of the Giant, this can be included in the significance of stage 2 of the process, and the sign that appears is Nobita who stands up with her knees resigned to her, which illustrates weakness. The object is Giant which forces Nobita.

The interpretation is that Nobita surrendered to Giant's compulsion. They consider themselves to be human beings the most important aspect on earth, while nature is its supporter,Nobita and Doraemon's farewell became the main attraction of the film "Stand by Me Doraemon". Plus, the film's visual appearance is so lively that the various expressions of Nobita and other characters can be clearly illustrated. Many valuable moral messages also color Nobita's struggle to change the course of her life. Unfortunately, some shortcomings are still present in the film.

By looking at tables and images, the researchers see that this is in line with what Barthes in Zaimar (2014, 23) says, "the sign can be interpreted openly, but limited by context, both the text itself and the socio-cultural context, as well as knowledge / the experience of the reader or viewer ". Signs do not have a stable meaning. Barthes's theory shows similarities and differences in terms of details of meaning. Barthes clearly divides meaning into denotation and context. It is in the name of both as a sign concept connected to the film, Coercion to Nobita was strengthened by Giant gesture. At the level of the nonverbal text, it can be seen how Giant leaned toward Nobita. Gesture illustrates a form of force by force. In addition, there is also a giant pointing at Nobita's face. Gesture illustrates certain firmness. So that it is reflected that Giant's coercion to Nobita is inevitable.

In this sequence, Nobita did not dare to resist or surrender to the coercion carried out by Giant. Reflected from the Nobita gesture that stands with the knees bent, open mouth with closed teeth illustrates shakiness or weakness and fear. The verbal and nonverbal signs in this sequence represent the concept of coercion accompanied by physical threats with the role of the Giant representing the concept of the perpetrator, and the role of Nobita representing the concept of the victim. Finally, in this study, researchers succeeded in revealing representations through nonverbal sequences in Doraemon Stand by Me.
Symbolic is identified with what is realized from the Imaginary order, whereas in Symbolic embedded values there is Signification and Signified. The symbolic here is the anime figure Nobita. Meanwhile, Doraemon is not only an elementary school child, but also has its own meanings for those who see it. Nobita is signi ficant, and meaning, which is generated when looking at Nobita is signified. Nobita can be said to be significant, because it is indeed the creation of a weak child. Whereas, the meaning is said to be signified.

The researcher has also been able to represent the concept of coercion and weakness with the role of Giant who represents the concept of the main actor, and the role of Nobita represents the concept of the victim. In researching a cultural product produced in a particular culture, it is necessary to understand that the content represented is an adaptation of the culture in which the cultural product is produced. In this study, researchers examined Doraemon cartoon series originating from Japan, which were later dubbed into Indonesian, so that there is a possibility of biased meaning of non-verbal texts that have been translated. Therefore, the researcher recommends researchers who are interested in conducting a representation study of a phenomenon in visual media to also examine cultural differences where the text originates when there is a reduction or strengthening of the meaning of the text.

\section{CONCLUSIONS}

The animated film Doraemon \& Nobita and the Green Giant Legend by Ayumu Watanabe released in 2018 is a film that raises issues about friendship, and can be studied using representation. Speech someone, in this case nonverbal speech acts has a communicative function in each delivery. One of the communicative functions in speech acts is expressive. The function of expressive speech acts aims to provide an evaluation or assessment of the things mentioned in the speech. Expressive speech can be determined by looking at the context when the speech occurs as representation.

The lesson we can learn in this Doraemon "stand by me" film is "who we are coming to, depending on what we do now". What we are trying to do now for our lives in the future is what we will learn. When we stimulate ourselves that if at the moment I don't work hard and pursue every dream I have. So in the future I will not be anything. I will only be mediocre. My presence is considered as a 
human being (there is or is not our presence, there will be no change). But if you do the opposite. Indeed Doraemon is just an animated film, which many people might consider to be the consumption of children. But you are wrong if you only think that this is only suitable for small children. Because there are many lessons that we can learn after completing this film.

Through this cartoon film, researchers try to find and interpret the symbols of Japanese culture represented through Doraemon, how Japanese people should be able to elevate their own culture into animasu films, and how they increase culture, by using semiotic analysis of culture and limited to in the area of non-verbal communication studies, researchers try to interpret what the author wants to convey through this film as a form of mass media

\section{REFERENCES}

Danesi, Marcell. (2002).Understanding Semiotics New York: Oxford University

Media Press.

Deddy Mulyana.(2005). Ilmu komunikasi Suatu Pengantar. PT Remaja Rosdakarya. Bandung

Kurniawan, Heru. (2009). Sastra Anak dalam Kajian Strukturalisme, Sosiologi, Semiotika, hingga Penulisan Kreatif. Yogyakarta : Graha Ilmu.

Sobur, Alex. (2003).Semiotika Komunikasi, PT Remaja Rosydakarya, Bandung.

Suheri Agus. (2006). Animasi Multimedia Pembelajaran. Jakarta : Elec media Komputindo.

Yusuf. A.Muri . (2014).Metodologi Penelitian Kuantitatif, Kualitatif \& Penelitan. Gabungan. Jakarta: Prenadamedia.

Zaimar, Okke Kusuma Sumantri..(2014). Semiotika dalam Analisis Karya Sastra. Depok : Komodo Books. 